Journal of Animal and Veterinary Advances 11 (11): 1917-1920, 2012

ISSN: $1680-5593$

(C) Medwell Journals, 2012

\title{
The Effect of Kepromec Pour-on Against Respiratory and Gastrointestinal Nematodes in Cows
}

\author{
${ }^{1}$ Amirparviz Rezaeisaber and ${ }^{2}$ Mehrdad Nazeri \\ ${ }^{1}$ Department of Clinical Science, ${ }^{2}$ Department of Veterinary Medicine, Tabriz Branch, \\ Islamic Azad University, Tabriz, Iran
}

\begin{abstract}
Internal parasitism of feedlot cattle has been documented to reduce performance and impair immune function. GI nematodes are chronic pervasive infections that contribute worldwide to morbidity and mortality in humans and in livestock. The objective of this study was to evaluation of Kepromec pour-on effect on decreasing of gastrointestinal nematodes. In this study, 60 male and female hybrid cows were allocated into two 30 individual groups. Then, Kepromec pour-on was administrated at the dose of $1 \mathrm{mg} 20 \mathrm{~kg}^{-1}$. Results showed that Kepromec pour-on has about $90 \%$ efficacy on GI nematodes. Thus, use of Kepromec to prohibition of GI nematodes is recommended.
\end{abstract}

$\underline{\text { Key words: Kepromec, respiratory and gastrointestinal tract, nematodes, cow, evaluation, Iran }}$

\section{INTRODUCTION}

Internal parasitism of feedlot cattle has been documented to reduce performance and impair immune function (Gomez-Munoz et al., 2004; Snider et al., 1986; Wiggin and Gibbs, 1990). GI nematodes are chronic pervasive infections that contribute worldwide to morbidity and mortality in humans (Albonico et al., 1999; Bundy et al., 1996; Hall and Chan, 1994; WHO, 1992) and in livestock (Coop and Holmes, 1996; Coop and Kyriazakis, 1999; Van Houtert and Sykes, 1996; Howlader et al., 2002; Ragbetli et al., 2009; Ceylan et al., 2010). Their co-existence with malnutrition has been recognized for decades by veterinarians and health care workers who have observed that malnutrition and intestinal parasitism share a similar geographical distribution with the same individuals experiencing both conditions simultaneously (Pelletier, 1994).

Researchers have explained this association by providing scientific evidence both that infection leads to malnutrition through impaired digestion and absorption (Stephenson and Holland, 1987) and that malnutrition increases susceptibility to infection through impaired local and systemic host defense mechanisms (Brandtzaeg, 1998; Ernst et al., 1999; Koski and Scott, 2001). Disease severity is typically related to worm burdens. Helminthiasis in small ruminant affects production losses due to mortalities; reduce weight gain and other losses of production (Chaudary et al., 2007). However, the effects of helminthes infections on production of particular livestock species depend mostly upon the age of the animal, breed, parasite species involved and the intensity of the worm population. Several factors are known to determine the epidemiological pattern of the associated disease condition. These include weather condition, husbandry practice and the physiological status of the animal (Khan et al., 1989; Tembely et al., 1997; Waller et al., 2004). Kepromec (22, 23-dihydroavermectin $\mathrm{B}_{1 \mathrm{a}}+22$, 23-dihydroavermectin $\mathrm{B}_{1 \mathrm{~b}}$ ) is a broad-spectrum antiparasitic avermectin medicine. It is sold under brand names Stromectol in the United States, Ivomec in Europe by Merial Animal Health, Mectizan in Canada by Merck and Ivexterm in Mexico by Valeant Pharmaceuticals International. It is traditionally used against worms. It is mainly used in animals and humans in the treatment of worm infestations (such as strongyloidiasis, ascariasis, trichuriasis, filariasis and enterobiasis).

Kepromec, under the brand name Mectizan is currently being used to help eliminate river blindness (onchocerciasis) in the Americas and stop transmission of lymphatic filariasis and onchocerciasis around the world. Currently, large amounts of kepromec are donated by Merck to fight river blindness in countries that are unable to afford the drug. The drug rapidly kills microfilariae but not the adult worms. A single oral dose of kepromec, taken annually for the 10-15 years life span of the adult worms is all that is needed to protect the individual from onchocerciasis. Kepromec and other avermectins

Corresponding Author: Amirparviz Rezaeisaber, Department of Clinical Science, Tabriz Branch, Islamic Azad University, Tabriz, Iran 
(insecticides most frequently used in home use ant baits) are macrocyclic lactones derived from the bacterium Streptomyces avermitilis. Kepromec kills by interfering with nervous system and muscle function in particular by enhancing inhibitory neurotransmission. The drug binds and activates Glutamate-gated Chloride channels (GluCls). GluCls are invertebrate-specific members of the Cys-loop family of ligand-gated ion channels present in neurons and myocytes.

\section{MATERIALS AND METHODS}

In this study researchers selected 60 male and female hybrid cows which are tested and approved that they have parasitic disease. Then, these animals were divided into 2 groups by chance, controls which are not received Kepromec pour-on and treatment group which are received Kepromec pour-on. In treatment group, Kepromec pour-on based on factory recommendation was administrated at dose of $1 \mathrm{~mL} / 10 \mathrm{~kg}$. After elapsing time, on days $1,7,21$ and 28 of study, samples were taken and to next measures were transported to Veterinary Faculty of Islamic Azad university, Tabriz branch. Then to recognizing the eggs and larva we used of Mc-Master Slide and Stoll Method methods, respectively. Data were analyzed by Dunn's multiple comparisons test and ANOVA test and $\mathrm{p}<0.001$ considered as significant differences.

\section{RESULTS AND DISCUSSION}

In this study obtained parasites from feces of cows includes: Trichostrongylus sp., Haemonchus sp., Trichuris sp., Nematodirus sp., Dictyocaulus sp. Mean Egg Per Gram of feces (EPG) and Larva Per Gram of feces (LPG) and effect of Kepromec pour-on in control of nematodes detected on different days after treatment are shown in Table 1 and 2. At the end of the study, based on below formula the effect of Kepromec pour-on at different days after treatment were calculated and are shown in Table 3 . Achieved data showed that kepromec pour-on has potent effect in controlling of the gastrointestinal nematodes.

Obtained data showed that kepromec pour-on has more effect (approximately 90\%) in prohibition of gastrointestinal parasites. This study is consistent with Uribe et al. (1989) researches results which have been reported that Ivermectin pour-on efficacy is $99 \%$. They also reported that this drug has preventive effect on protozoan such as Eimeria, Amoeba and Cryptosporidium

Table 1: Mean of EPG in treatment and control groups before and after treatment

\begin{tabular}{|c|c|c|c|c|c|c|}
\hline \multirow[b]{2}{*}{ Groups } & \multirow[b]{2}{*}{ Parasites } & \multicolumn{5}{|l|}{ Mean of EPG } \\
\hline & & $\begin{array}{c}\text { Mean of } 3 \text { enumeration } \\
\text { before treatment }\end{array}$ & $\begin{array}{c}1 \text { day after } \\
\text { treatment }\end{array}$ & $\begin{array}{c}7 \text { days after } \\
\text { treatment }\end{array}$ & $\begin{array}{c}21 \text { days after } \\
\text { treatment }\end{array}$ & $\begin{array}{c}28 \text { days after } \\
\text { treatment }\end{array}$ \\
\hline \multirow[t]{4}{*}{ Treatment group } & Trichostrongylus colubriformis & 730 & 152 & 18 & 7 & - \\
\hline & Haemonchus contortus & 1280 & 320 & 24 & 3 & 1 \\
\hline & Trichuris trichiura & 520 & 56 & 34 & 2 & - \\
\hline & Nematodirus spathiger & 780 & 34 & 12 & 5 & 2 \\
\hline \multirow[t]{4}{*}{ Control group } & Trichostrongylus colubriformis & 730 & 728 & 690 & 862 & 891 \\
\hline & Haemonchus contortus & 1280 & 1072 & 820 & 942 & 913 \\
\hline & Trichuris trichiura & 520 & 493 & 524 & 681 & 702 \\
\hline & Nematodirus spathiger & 780 & 582 & 638 & 612 & 520 \\
\hline
\end{tabular}

Table 2: Mean of LPG in treatment and control groups before and after treatment

\begin{tabular}{|c|c|c|c|c|c|c|}
\hline \multirow[b]{2}{*}{ Groups } & \multirow[b]{2}{*}{ Parasites } & \multicolumn{5}{|l|}{ Mean of LPG } \\
\hline & & $\begin{array}{l}\text { Mean of } 3 \text { enumeration } \\
\text { before treatment }\end{array}$ & $\begin{array}{l}1 \text { day after } \\
\text { treatment }\end{array}$ & $\begin{array}{c}7 \text { days after } \\
\text { treatment }\end{array}$ & $\begin{array}{c}21 \text { days after } \\
\text { treatment }\end{array}$ & $\begin{array}{c}28 \text { days after } \\
\text { treatment }\end{array}$ \\
\hline Treatment group & Dictyocaulus viviparus & 486 & 401 & 320 & 12 & - \\
\hline Control group & Dictyocaulus viviparus & 486 & 492 & 524 & 561 & 598 \\
\hline
\end{tabular}

Table 3: Effect of Kepromec pour-on at different days after treatment

\begin{tabular}{lccc}
\hline Parasites & $\begin{array}{c}\text { Drug efficacy on day 1 } \\
\text { after treatment (\%) }\end{array}$ & $\begin{array}{c}\text { Drug efficacy on day 7 } \\
\text { after treatment (\%) }\end{array}$ & $\begin{array}{c}\text { Drug efficacy on day } 21 \\
\text { after treatment (\%) }\end{array}$ \\
\hline Trichostrongylus colubriformis & 80.56 & 97.39 & $\begin{array}{c}\text { Drug efficacy on day 28 } \\
\text { after treatment (\%) }\end{array}$ \\
Haemonchus contortus & 70.14 & 97.07 & 99.18 \\
Trichuris trichiura & 88.64 & 93.72 & 99.68 \\
Nematodirus spathiger & 94.15 & 98.11 & 99.70 \\
Dictyocaulus viviparus & 18.49 & 38.93 & 99.18 \\
\hline
\end{tabular}


(Uribe et al., 1989). Based on researcher's reports, Ivermectin $0.4 \mathrm{mg} / \mathrm{kg} / \mathrm{BW}$ as tablet for 10 weeks decreases $100 \%$ of eggs and at the dose of $0.2 \mathrm{mg} / \mathrm{kg} / \mathrm{BW}$ as subcutaneous and at the dose of $0.5 \mathrm{mg} / \mathrm{kg} / \mathrm{BW}$ as pour-on route not only controlled parasitic infections but prevented of new patent natural infections. Also, in other study revealed that Ivermectin at the dose of $0.5 \mathrm{mg} / \mathrm{kg} / \mathrm{BW}$ were effective on Haemonchus contortus, Oesphagustomum columbianum, Bunostomum phlebostomum and Thalazia species (Adams, 1995; Campbell and Benz, 1984; Egerton et al., 1988; Garg et al., 2007).

\section{CONCLUSION}

In this study, results demonstrate that genesis Ivermectin pour-on has high effect on gastrointestinal nematodes and use of this drug to controlling and prevention of parasitic infections is recommended.

\section{REFERENCES}

Adams, H.R., 1995. Ivermectin. In: Veterinary Pharmacology and Therapeutics, Adams, H.R. (Ed.). 7th Edn., Iowa State University Press, Ames, IA., USA., pp: 916- 930.

Albonico, M., D.W. Crompton and L. Savioli, 1999. Control strategies for human intestinal nematode infections. Adv. Parasitol., 42: 277-341.

Brandtzaeg, P., 1998. Development and basic mechanisms of human gut immunity. Nutr. Rev., 56: S5-18.

Bundy, R.E., J.S. Owen, V.L. Lima and E.M. Chaves, 1996. Trypanolytic activity in vivo of plasma from patients with schistosomiasis against the African trypanosome, Trypanosoma brucei brucei. Biochem. Soc. Trans., 24: 439S-439S.

Campbell, W.C. and G.W. Benz, 1984. Ivermectin: A review of efficacy and safety. J. Vet. Pharmacol. Ther., 7: 1-16.

Ceylan, E., C. Ragbetli and P. Tanritanir, 2010. Evaluating the effect of the treatment of doramectin on some biochemical parameters in goats naturally infected with gastrointestinal nematodes. Asian J. Anim. Vet. Adv., 5: 162-168.

Chaudary, F.R., M.F.U. Khan and M. Qayyum, 2007. Prevalence of Haemonchus contortus in naturally infected small ruminants grazing in the Photohar area of Pakistan. Pak. Vet. J., 27: 73-79.

Coop, R.L. and I. Kyriazakis, 1999. Nutrition-parasite interaction. Vet. Parasitol., 84: 187-204.
Coop, R.L. and P.H. Holmes, 1996. Nutrition and parasite interaction. Int. J. Parasitol., 26: 951-962.

Egerton, J.R., D. Suhayda and C.H. Eary, 1988. Laboratory selection of Haemonchus contortus for resistance to ivermectin. J. Parasitol., 74: 614-617.

Ernst, P.B., F. Song, G.R. Klimpel, H. Haeberle and K.B. Bamford et al., 1999. Regulation of the mucosal immune response. Am. J. Trop. Med. Hyg., 60: 2-9.

Garg, R., R.R. Kumar, C.L. Yadav and P.S. Banerjee, 2007. Duration of anthelmintic effect of three formulations of ivermectin (Oral, Injectable and Pour-on) against multiple anthelmintic-resistant Haemonchus contortus in sheep. Vet. Res. Commun., 31: 749-755.

Gomez-Munoz, M.T., A. Canals-Caballero, S. Almeria, P. Pasquali, D.S. Zarlenga and L.C. Gasbarre, 2004. Inhibition of bovine $\mathrm{T}$ lymphocyte responses by extracts of the stomach worm Ostertagia ostertagi. Vet. Parasitol., 120: 199-214.

Hall, A. and M.S. Chan, 1994. Intestinal worms: Strategies to control disease. Afr. Health, 17: 23-26.

Howlader, M.M.R., A.T.M. Mahbub-e-Elahi, S. Habib, M.J.U. Bhuyan, M.A.B. Siddique, M.A. Haye and M.G. Hossain, 2002. Gastro-intestinal nematode infestations in the black Bengal goats of Sirajgong district of Bangladesh. J. Biological Sci., 2: 556-557.

Khan, M.N., C.S. Hayat, A.H. Chaudhry, Z. Iqbal and B. Hayat, 1989. Prevalence of gastrointestinal helminths in sheep and goats at Faisalabad abattoir. Pak. Vet. J., 9: 159-161.

Koski, K.G. and M.E. Scott, 2001. Gastrointestinal nematodes, nutrition and immunity: Breaking the negative spiral. Annu. Rev. Nutr., 21: 297-321.

Pelletier, D.L., 1994. The potentiating effects of malnutrition on child mortality: Epidemiologic evidence and policy implications. Nutr. Rev., 52: 409-415.

Ragbetli, C., E. Ceylan and P. Tanritanir, 2009. The efficacy of moxidectin against gastrointestinal nematode infections in goats. Asian J. Anim. Vet. Adv., 4: 134-138.

Snider, T.G. 3rd, J.C. Williams, P.A. Karns, T.L. Romaire, H.E. Trammel and M.T. Kearney, 1986. Immunosuppression of lymphocyte blastogenesis in cattle infected with Ostertagia ostertagi and/or Trichostrongylus axei. Vet. Immunol. Immunopathol., 11: 251-264.

Stephenson, L.S. and C. Holland, 1987. The Impact of Helminth Infections on Human Nutrition: Schistosomes and Soil-Transmitted Helminths. Taylor and Francis, London, UK., ISBN-13: 9780850663679, Pages: 233. 
Tembely, S., A. Lahlou-kassi, J.E.O. Rege, S. Sovani, M.L. Diedhiou and R.L. Baker, 1997. The epidemiology of nematode infections in sheep in a cool tropical environment. Vet. Parasitol., 70: 129-1 41.

Uribe, L.F., P.F. McMullin, L.G. Cramer and N.K. Amaral, 1989. Topically applied ivermectin: Efficacy against torsalo (Diptera: Cuterebridae). J. Econ. Entomol., 82: 847-849.

Van Houtert, M.F. and A.R. Sykes, 1996. Implications of nutrition for the ability of ruminants to withstand gastrointestinal nematode infections. Int. J. Parasitol., 26: 1151-1167.
WHO, 1992. Health of schoolchildrens treatment of intestinal helminths and schistosomiasis. WHO/CDC/ IPI/CTD/92.1 WHO, Geneva.

Waller, P.J., L. Rudby-Martin, B.L. Ljungstrom and A. Rydzik, 2004. The epidemiology of abomasal nematodes of sheep in Sweden, with particular reference to over-winter survival strategies. Vet. Parasitol., 122: 207-220.

Wiggin, C.J. and H.C. Gibbs, 1990. Adverse immune reactions and the pathogenesis of Ostertagia ostertagi infections in calves. Am. J. Vet. Res., 51: 825-832. 